\title{
Predicting the geographic distribution habitats of Schizomyia buboniae (Diptera: Cecidomyiidae) and its host plant Deverra tortuosa (Apiaceae) in Egypt by using MaxEnt modeling
}

\author{
Mohamed Kamel ${ }^{1 *}$ (D, Ahmed S. Bream² ${ }^{2}$ Mohamed M. Moursy ${ }^{3}$ and Sanad H. Ragab²
}

\begin{abstract}
Background: In some localities of the Mediterranean coast and the Nile land region, the gall midge Schizomyia buboniae Frauenfeld, 1859 (Diptera: Cecidomyiidae) induce small barrel-shaped galls on the stem of Deverra tortuosa (Desf.) DC. (Family: Apiaceae). Host plants interact with several insects in a different manner. The current work studies the interaction of S. buboniae with D. tortuosa. Furthermore, the present work predicted the distribution of S. buboniae and its host plant D. tortuosa in Egypt by using MaxEnt modeling, in addition to the effect of elevation and vegetation cover on its distribution.

Results: The predominance of S. buboniae occurred during late winter to spring. The S. buboniae larvae are occasionally attacked by endoparasitoids of the genus Inostemma (Platygastridae). There was a significant positive correlation between the number of galls per plant and the plant cover within the study localities. Meanwhile, there was no significant correlation between the number of galls per plant and the altitude within the study localities. Also, the high temperature and altitude were the most important predictors for the habitat distribution of $S$. buboniae and its host plant $D$. tortuosa. The predicted distribution range size for $S$. buboniae is less than the total predicted distribution range size for $D$. tortuosa.

Conclusions: The current study suggests that the gall inducer prefers large plants more than small ones. The present study suggests that the habitat distribution patterns of S. buboniae and its host plant D. tortuosa in Egypt can be modeled using a small number of occurrence records together with environmental variable layers for the study area through the maximum entropy modeling technique.
\end{abstract}

Keywords: Galls, Prediction, Mediterranean coast, Interactions, Climatic variable

\section{Background}

Plant galls and other types of disease found on host plants have motivated many researchers to conduct studies into the mechanism of gall formation (Hori, 1976). Plant galls are neo-shaped structures in plant

\footnotetext{
* Correspondence: Mohamed.kamel@iesr.asu.edu.eg

${ }^{1}$ Department of Environmental Basic Sciences, Institute of Environmental

Studies and Research, Ain shams University, Cairo, Egypt

Full list of author information is available at the end of the article
}

tissues arising from cellular hyperplasia and hypertrophy that can situate in various plant organs such as the stems, leaves, flowers, fruits, roots, and axillary buds (Ascendino \& Maia, 2018; Santos, Hanson, Maia, \& Mehltreter, 2018). Galls are most often observed as swollen, large growths on a leaf, branch petiole, or twig (Royer \& Rebek, 2013). These are induced by various organisms such as fungi, bacteria, viruses, nematodes, mites, and insects (Barbosa \& Wagner, 1989). Gall

\section{Springer Open}

() The Author(s). 2021 Open Access This article is licensed under a Creative Commons Attribution 4.0 International License, which permits use, sharing, adaptation, distribution and reproduction in any medium or format, as long as you give appropriate credit to the original author(s) and the source, provide a link to the Creative Commons licence, and indicate if changes were made. The images or other third party material in this article are included in the article's Creative Commons licence, unless indicated otherwise in a credit line to the material. If material is not included in the article's Creative Commons licence and your intended use is not permitted by statutory regulation or exceeds the permitted use, you will need to obtain permission directly from the copyright holder. To view a copy of this licence, visit http://creativecommons.org/licenses/by/4.0/. 
formation involves an intimate parasitic interaction between the gall maker and its host plant (Rocha et al., 2013). Galls supply nutrition, assurance, and shelter to the gall-inducing insects or their offspring (Ascendino \& Maia, 2018).

Gall-inducing insects are remarkable bioindicators of any alters in the environment and habitat quality due to their host specificity, close-fitting habit, abundance, and easy localization (Julião, Fernandes, Negreiros, Bedê, \& Araújo, 2005; Santana \& Isaias, 2014). The diversity of gall-inducing insects reflects the conservation status of an ecosystem (Santana \& Isaias, 2014).

Gall-inducing insects may provide a vital tool to evaluate habitat quality and restoration (Kamel, 2021). Their species richness was used as indicators of forest age and health (Fernandes, Almada, \& Carneiro, 2010), and they were used as bioindicators of habitat restoration in a degraded land of Atlantic Forest (Moreira, Fernandes, Almada, \& Santos, 2007).

A question of great interest is how gall-inducing insects are affected by several biotic and abiotic variables. The plant structural complexity, the altitudinal/latitudinal gradient, and the host plant geographical range size are the main factors that may affect the richness and diversity of gall-inducing insects (Fernandes et al., 2010; Kamel, 2012; Roininen et al., 2006). The physical structure of the aerial vegetation parts of the host plant affects the community structure of gall insects (Araújo, De Paula, Carneiro, \& Schoereder, 2006a). Additionally, leaf size and shoot diameter may also affect the gall induction (Fritz, Gaud, Sacchi, \& Price, 1987; Yamazaki \& Ohsaki, 2006).

Gall-forming species is about $2 \%$ of the total named insect species (Dreger-Jauffret, 1992; Raman, Schaefer, Withers, \& Enfield, 2005). Cecidomyiidae (Diptera: Nematocera) are the youngest, largest, and most diverse subfamily of gall midges that hold more than 6651 species (Gagné \& Jaschhof, 2004; Gagné \& Jaschhof, 2021). Cecidomyiidae have a cosmopolitan distribution; therefore, Cecidomyiidae is estimated to be the richest taxon in the kingdom Animalia with over 1.8 million species worldwide (Hebert et al., 2016). Gall-forming insects have an important role in pollination (Borges, 2015). Some of Cecidomyiidae gall midge species are economically important; it can make damage to agricultural plants (Darvas, Skuhravá, \& Andersen, 2000) and to forest trees (Skuhravá \& Roques, 2000). Some galls contain tanins which are used for tanning and for medicinal purposes from India to Algiers (Gerling, Kugler, \& Lupo, 1976).

Recently, many gall midges were recorded inducing different types of plant galls in several regions of Egypt (Doğanlar \& Elsayed, 2013; Doğanlar \& Elsayed, 2015; Elsayed \& Karam, 2016; Elsayed, Karam, \& Tokuda,
2017; Elsayed, Skuhrava, Karam, Elminshawy, \& AlEryan, M. A., 2015; Kamel, 2012; Kamel, 2021; Kamel, Semida, \& Abdel-Dayem, 2012).

Schizomyia is a genus of gall midges. It is characterized by a cosmopolitan distribution (Elsayed et al., 2019; Elsayed, Lin, Yang, \& Tokuda, 2020; Elsayed, Yukawa, \& Tokuda, 2018; Frauenfeld, 1859). In the coastal desert habitat, Schizomyia buboniae (Frauenfeld, 1859) induces berry-like galls on the stems of Deverra tortuosa (Skuhravá, Skuhravý, \& Elsayed, 2014). It was collected before in some areas of Egypt such as Suez, Wadi Degla Protectorate in Cairo, and Burg El-Arab (Alexandria). (Frauenfeld, 1859; Skuhravá et al., 2014). This species is univoltine, with galls apparent on the host from late $f$ February to early April. Pupation takes place inside the gall, and adults emerge from March to April (Dorchin \& freidberg, 2011; Skuhravá et al., 2014).

Deverra tortuosa (Desf.) DC. (Family: Apiaceae) is recorded as a common associate in most plant communities located in the coastal and inland desert habitats (Serag, Khedr, \& Amer, 2020). Deverra tortuosa is one of the most important medicinal plants in Egypt. It is utilized in folk medicine as a diuretic, carminative, antiasthmatic, and analgesic against hypertension, constipation, fever, headache, and bites (Azzazi, Afifi, Tammam, \& Sheikh Alsouk, A., 2015; El-Mokasabi, 2014). D. tortuosa resists against intestinal parasites and stomach pain (Azzazi et al., 2015). The Deverra extracts showed high scavenging and anti-oxidant properties under stress conditions (El-lamey, 2015a). D. tortuosa has high palatability for several grazing animals (Boulos, 2000). The plant grows in desert wadis and stony and sandy plains, and it is located in Egypt, Palestine, Saudi Arabia, Libya, and Tunisia (Boulos, 2000).

Species distribution models (SDMs) are an efficient tool for assessing the potential for species to exist in regions not previously surveyed (Guisan \& Thuiller, 2005). These models have been used for providing a baseline for predicting a species' response to landscape variance and/or climate change (Araújo, Thuiller, \& Pearson, 2006b) and for recognizing the important areas for conservation (Wilson, Westphal, Possingham, \& Elith, 2005). Several studies indicated that a statistical mechanics approach as the MaxEnt technique performs very well even with small samples (Hernandez, Graham, Master, \& Albert, 2006; Phillips, Anderson, \& Schapire, 2006). Some studies were performed using species distribution models for predicting the geographic distribution of various species in Egypt (El Alqamy et al., 2010; Kamel et al., 2012).

Therefore, the main goal of this study was to investigate the interaction of $S$. buboniae with $D$. tortuosa in some regions of the Mediterranean coast in Egypt and study the effect of elevation and vegetation cover on gall 
Table 1 The recorded locations of D. tortuosa in Egypt

\begin{tabular}{|c|c|c|c|c|}
\hline \multirow[t]{2}{*}{ No. } & \multirow[t]{2}{*}{ Location } & \multicolumn{2}{|c|}{ Coordinates } & \multirow[t]{2}{*}{ References } \\
\hline & & Latitude & Longitude & \\
\hline 1 & Wadi Degla, Cairo & 29.96 & 31.32955 & (Chrtek, Osbornova, \& Sourkova, 1967) \\
\hline 2 & Wadi El Natrun, El Alamein Road & 30.657 & 29.603 & (El-Lamey, 2015b) \\
\hline 3 & Ras El Hekmah & 31.1179 & 27.823 & (Chrtek et al., 1967) \\
\hline 4 & Wadi Hoff & 29.916 & 31.3779 & (Chrtek et al., 1967) \\
\hline 5 & Cairo-Suez Road & 30.118 & 31.635 & (Chrtek et al., 1967) \\
\hline 6 & Cairo-Suez Road & 30.1042 & 31.7443 & (Chrtek et al., 1967) \\
\hline 7 & Cairo-Suez Road & 30.0923 & 31.8682 & (Chrtek et al., 1967) \\
\hline 8 & Cairo-Suez Road & 30.08816 & 31.9444 & (Chrtek et al., 1967) \\
\hline 9 & Wadi Sudr, Ras Sudr & 29.500 & 32.700 & (El-Lamey, 2015b) \\
\hline 10 & Wadi Sudr, Ras Sudr & 30.300 & 30.1000 & (El-Lamey, 2015b) \\
\hline 11 & Wadi Sudr, Ras Sudr & 30.700 & 29.400 & (El-Lamey, 2015b) \\
\hline 12 & $18 \mathrm{~km}$ west of Mersa Matruh & 31.250 & 27.387 & (El-Lamey, 2015b) \\
\hline 13 & $46 \mathrm{~km}$ coastal road before Mersa Matruh & 31.1337 & 27.666 & (Chrtek et al., 1967) \\
\hline 14 & Ras El Hekma & 27.816 & 31.887 & (Chrtek et al., 1967) \\
\hline 15 & Wadi Natrun & 30.338167 & 30.406389 & (Chrtek et al., 1967) \\
\hline 16 & Cairo-Alexandria Desert Road & 30.392 & 30.376 & (Chrtek et al., 1967) \\
\hline 17 & Pyramids, Giza & 29.980 & 31.129 & (Chrtek et al., 1967) \\
\hline 18 & Pyramids, Giza & 29.982 & 31.132 & (Chrtek et al., 1967) \\
\hline 19 & Ismailia City & 30.6043 & 32.2578 & (Chrtek et al., 1967) \\
\hline 20 & 4 km from Ain Soklma & 29.639 & 32.3078 & (Chrtek et al., 1967) \\
\hline 21 & Helwan & 29.8404 & 31.2983 & (Chrtek et al., 1967) \\
\hline 22 & WADI Qusseib, coast of Gulf of Suez & 29.0515 & 33.2051 & (Chrtek et al., 1967) \\
\hline 23 & Moghra Oasis & 30.2506 & 28.9367 & (Chrtek et al., 1967) \\
\hline 24 & Wadi Aber of Gebl Ataqa & 29.9259 & 32.3631 & (Chrtek et al., 1967) \\
\hline 25 & Sakkara, Cairo & 29.8590 & 31.1352 & (Chrtek et al., 1967) \\
\hline 26 & 6 October & 30.90133 & 29.544444 & (Abd El-Ghani, Bornkamm, El-Sawaf, \& Turky, 2011) \\
\hline 27 & Farsh Shoeab & 28.5527 & 33.9668 & (Kamel et al., 2012) \\
\hline 28 & Wadi El-Deer & 28.55776 & 33.97799 & (Kamel et al., 2012) \\
\hline 29 & Wadi El Arbain & 28.55269 & 33.94931 & (Kamel et al., 2012) \\
\hline 30 & Wadi Telah & 28.5765 & 33.92702 & (Kamel et al., 2012) \\
\hline 31 & El-Gabal El-Molawan & 28.58151 & 34.06413 & (Kamel et al., 2012) \\
\hline
\end{tabular}

induction. Furthermore, this study tried to estimate the geographic distribution habitats of $S$. buboniae and its host plant $D$. tortuosa in Egypt using the maximum entropy modeling technique (MaxEnt) for searching the suitable areas of the gall maker S. buboniae and its host plant D. tortuosa in Egypt, which should be the important areas for conservation.

\section{Methods}

\section{Study area}

The floral territories of Egypt may be divided into the Mediterranean coast, the Nile land, and the deserts and mountains (El Hadidi \& Hosni, 1996). Egypt's Mediterranean coast (north coast) extends from Sallum for approximately $970 \mathrm{~km}$ east to Rafah, with an approximate width of $15-20 \mathrm{~km}$ in a north-south direction (Hadidi,
1981). According to Zahran, El Demerdash, and Mashaly (1985) and Zahran, El-Demerdash, and Mashaly (1990), the north coast is ecologically divided into three sections; western (the Mareotis, spreading for $550 \mathrm{~km}$ between Sallum and Alexandria), middle (deltaic, spreading for $180 \mathrm{~km}$ between Alexandria and Port Said), and eastern (Sinaitic, spreading for $220 \mathrm{~km}$ between Port Said and Rafah).

The current study was conducted in some regions of the Mediterranean coast, in addition to some localities in the Nile land region. The chosen sampling sites for D. tortuosa were El Sadat City, El Nubariyah, Wadi El Natrun, El Amria, and El Alamein City (Fig. 6). The study sites were visited periodically in the period from February 2019 to June 2020, once every 2 months. 
Table 2 Definitions of the climatic variable abbreviations

\begin{tabular}{ll}
\hline & Variable definition \\
\hline Bio1 & Annual mean temperature \\
Bio2 & Mean diurnal range (mean of monthly (max temp - min temp)) \\
Bio3 & Isothermality $($ P2/P7) $(\times 100)$ \\
Bio4 & Temperature seasonality (standard deviation $\times 100)$ \\
Bio5 & Max temperature of the warmest month \\
Bio6 & Min temperature of the coldest month \\
Bio7 & Temperature annual range (P5-P6) \\
Bio8 & Mean temperature of the wettest quarter \\
Bio9 & Mean temperature of the driest quarter \\
Bio10 & Mean temperature of the warmest quarter \\
Bio11 & Mean temperature of the coldest quarter \\
Bio12 & Annual precipitation \\
Bio13 & Precipitation of the wettest month \\
Bio14 & Precipitation of the driest month \\
Bio15 & Precipitation seasonality (coefficient of variation) \\
Bio16 & Precipitation of the wettest quarter \\
Bio17 & Precipitation of the driest quarter \\
Bio18 & Precipitation of the warmest quarter \\
Bio19 & Precipitation of the coldest quarter \\
\hline
\end{tabular}

\section{Study plants}

Deverra tortuosa (Desf.) DC. (Family: Apiaceae) is strongly aromatic glabrous and densely branched perennial shrub $(30-80 \mathrm{~cm})$, the plant stems are dichotomously branched, the leaves are caduceus, the flowers' petals are almost glabrous, and the fruit is sparingly hairy and globose (Boulos, 2000; Migahid, 1989). The recorded locations of D. tortuosa in Egypt are shown in Fig. 2 and Table 1.

\section{Samples collection and identification}

The size of each plant within the sample was measured using a tape meter for calculating plant cover (the ground area obscured by the plant's biomass when viewed from above) (Qi, Wei, Chen, \& Chen, 2019) according to formula the (average width/100/2) ${ }^{\wedge} 2 \times(22 /$ 7 ), in addition to the number of galls on different parts of the plant. Plant samples were identified according to Boulos (2000) and Migahid (1989). The immature stages of the gall inducer inside the galls were collected from the field and reared in the laboratory until the adults emerge; gall midge specimens are preserved in vials with $75 \%$ alcohol. The manipulation of the specimens was carried out under a stereomicroscope (model MБC-9, USSR) using a dissecting needle and a very delicate small forceps to prevent the sample distortions.

\section{Data analysis}

The collected data were analyzed using the SPSS computer package (PASW statistics ver.18, 2009). The
Spearman correlation test was used to measure the relationship between altitude, plant size, and the number of galls per plant. Also, the one-way ANOVA test was used to compare the mean number of galls per plant between different localities.

\section{Mapping and predicting distributions of plant species}

The presence locations for Deverra tortuosa are recorded using GPS (Garmin XL 12). The Maxent software (version 3.3.1) is utilized to predict the potential distribution of the plant species using the presence data (recorded distribution) together with environmental variable layers for the study area, such as altitude, temperature, and moisture (Phillips et al., 2006; Phillips, Dudík, \& Schapire, 2004).

\section{Environmental data of the model}

The model used various datasets as raster grids. Data were classified into climatic variables and topographical data. Nineteen bioclimatic variables (Table 2) are used to define the eco-physiological tolerances of a species (Graham \& Hijmans, 2006). These were obtained from the WorldClim dataset (Hijmans, Cameron, Parra, Jones, \& Jarvis, 2005; http://www.worldclim.org/bioclim.htm). Altitude is the most topographic data that was utilized as a partial dataset $(\sim 1 \mathrm{~km})$ from the Shuttle Radar Topography Mission (SRTM). Moreover, we obtained retrospective distributional data for Deverra tortuosa from published literature besides our reliable observational data. When specific geographic coordinates were not provided for a locality, we used maps and gazetteers to assign geographical coordinates to these records.

\section{Statistical validation of the model}

An extrinsic and independent test datasets were used to assess the predictive performance of the model (randomly data partition into $75 \%$ of the points was used to build the model and to predict species "training data" and $25 \%$ for model testing "testing data"). Statistical validation of the model was performed by comparing the extrinsic omission rates (i.e., proportion of test localities falling outside the prediction for each algorithm) with calculations of the area under the curve (AUC) of the receiver operating characteristic (ROC). The area under the curve (AUC) is used as a measure of the accuracy of the model (Phillips, 2016). The AUC ranges from 0 to 1. An AUC of 0.5 indicates a model that is no better than random, while an AUC of 1 indicates a perfect model (Phillips et al., 2004; Phillips et al., 2006). The current study used the AUC classification system provided by Hosmer, Lemeshow, and Cook (2000). That system classifies the AUC values as follows: $0.5-0.6=$ no discrimination, $0.6-0.7=$ poor discrimination, $0.7-0.8=$ acceptable discrimination, $0.8-0.9=$ excellent 


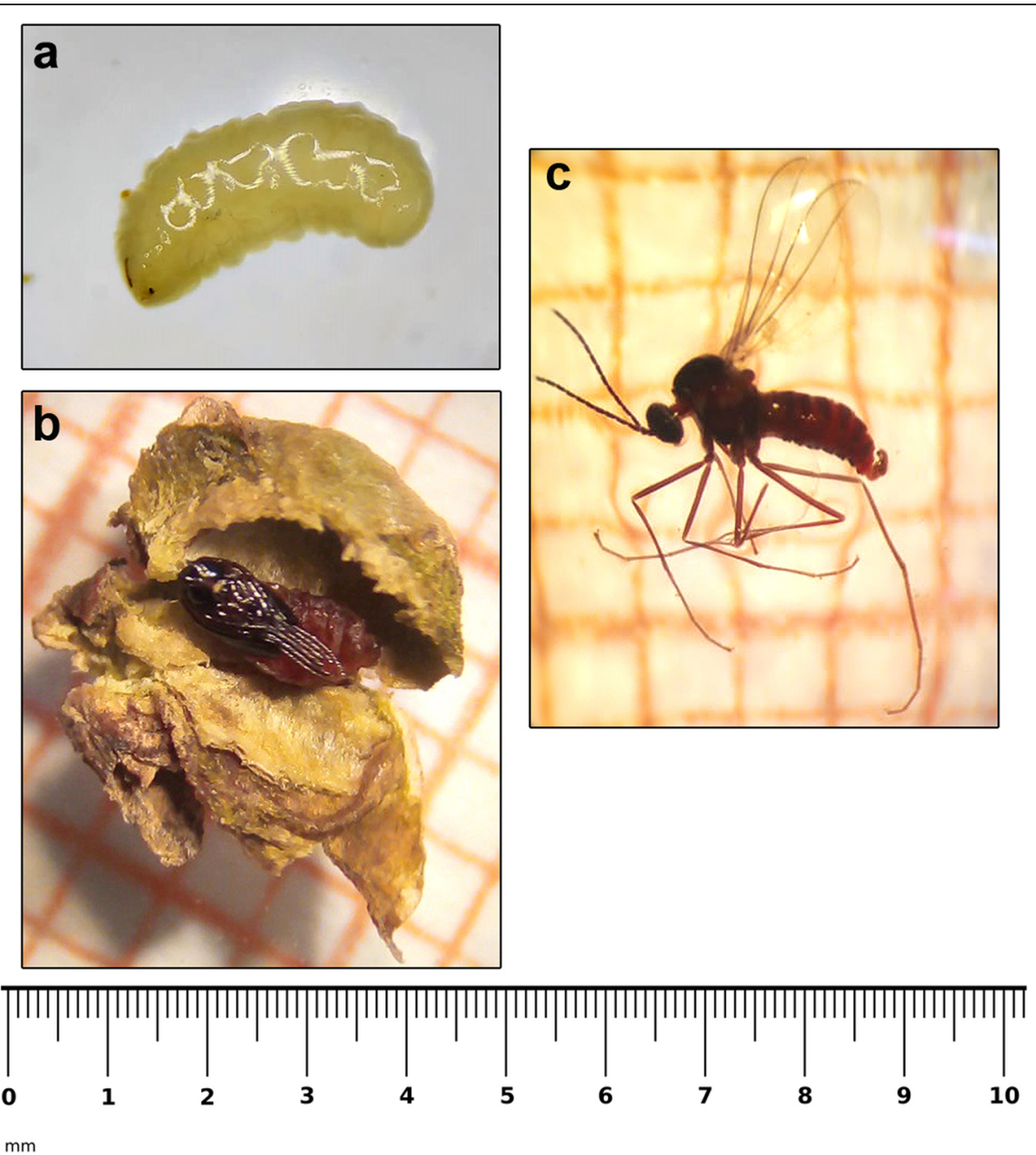

Fig. 1 The gall midge Schizomyia buboniae Frauenfeld, 1859 (Diptera: Cecidomyiidae). a Ethanol-preserved larvae (3 mm), b pupa (3 mm), and c adult $(2.5 \mathrm{~mm})$

discrimination, and $0.9-1.0=$ outstanding discrimination (Hosmer et al., 2000). The percentage contribution of each variable to the final model was provided by MaxEnt; the contribution values are determined by the increase in gain of the model provided by each variable (Phillips et al., 2006). The MaxEnt model's internal

Table 3 Gall induction on Deverra tortuosa within the study area

\begin{tabular}{lll}
\hline Location & Number of host plant & Number of galls \\
\hline El Sadat city & 34 & 212 \\
Wadi El Natrun & 5 & 12 \\
EL Nubariyah & 2 & 4 \\
El Amria & 6 & 17 \\
El Alamein & 44 & 147 \\
Total & $\mathbf{9 1}$ & $\mathbf{3 9 2}$ \\
\hline
\end{tabular}

jackknife test was used to determine which variables contribute most to the model development.

\section{Results}

Gall morphology and life history of Schizomyia buboniae (Diptera: Cecidomyiidae)

The gall midge S. buboniae (Fig. 1) induced 392 galls on 91 individuals of $D$. tortuosa within the study area (Table 3). The galls (Fig. 2) develop on the stems of Deverra tortuosa and appear as globular aggregations of 10-50 small barrel-shaped assemblages, resulting in a delicate berry-like structure, $1.5-3 \mathrm{~cm}$ in diameter. Each barrel-shaped chamber of the gall contains a single larva. Pupation takes place inside the gall (Fig. 1 ), and one generation is recorded during a year. The fresh gall is green in February and soon converts to yellow and then brown after adult gall midges emerge from it in early April to the end of May. The $S$. 


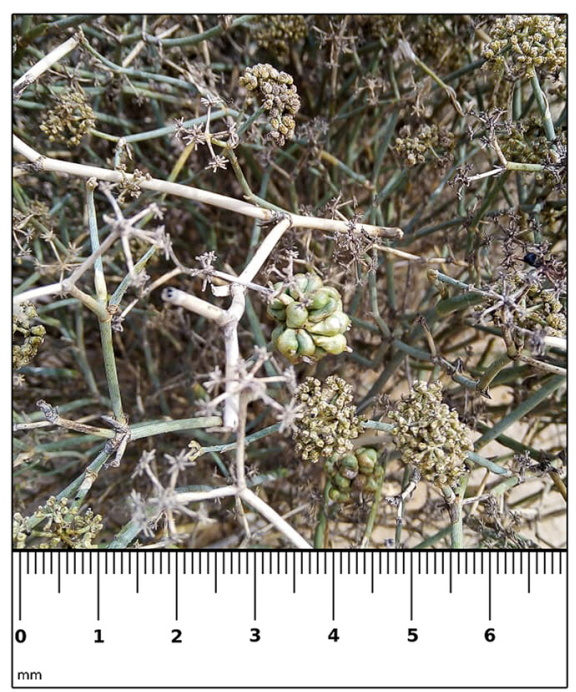

Fig. 2 The berry-like galls of Schizomyia buboniae (1.5-2.5 mm)

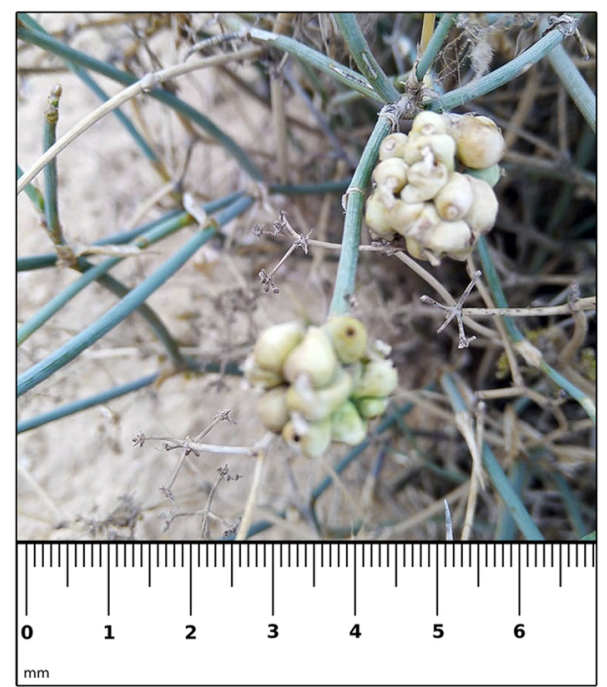

buboniae larvae are occasionally attacked by endoparasitoids of the genus Inostemma (Platygastridae) (Fig. $3)$.

Factors affecting the distribution of Schizomyia buboniae on Deverra tortuosa Correlation between the number of galls per plant, plant cover, and altitude

There was a significant positive correlation between the number of galls per plant and the plant cover within the study localities ( $\mathrm{rs}=0.340, P<0.01$ ) (Fig. 4). Meanwhile, there was no significant correlation between the number of galls per plant and the altitude within the study localities ( $\mathrm{rs}=-0.105, P=0.354$ ).

\section{Spatial distribution of the number of galls induced on Deverra tortuosa among different localities}

There was a significant difference in the number of galls induced on Deverra tortuosa among different localities (El Sadat City, EL Nubariyah, Wadi El Natrun, El Amria, and El Alamein City $)(F(4,86)=$ 2.611, $P<0.05$ ) (Fig. 5). El Sadat City showed the greatest mean number of galls per plant, 6.24, as compared to 2, 2.4, 2.83, and 3.34 at EL Nubariyah, Wadi El Natrun, El Amria, and El Alamein City, respectively.

The post hoc test according to Tukey's method is performed to test multiple comparisons between different study localities in the distribution of the number of galls induced on Deverra tortuosa. There was a significant difference between El Sadat City and El Alamein City equal to $2.89(P<0.05)$.

Fig. 3 Inostemma sp. (Platygastridae) (2 mm) 


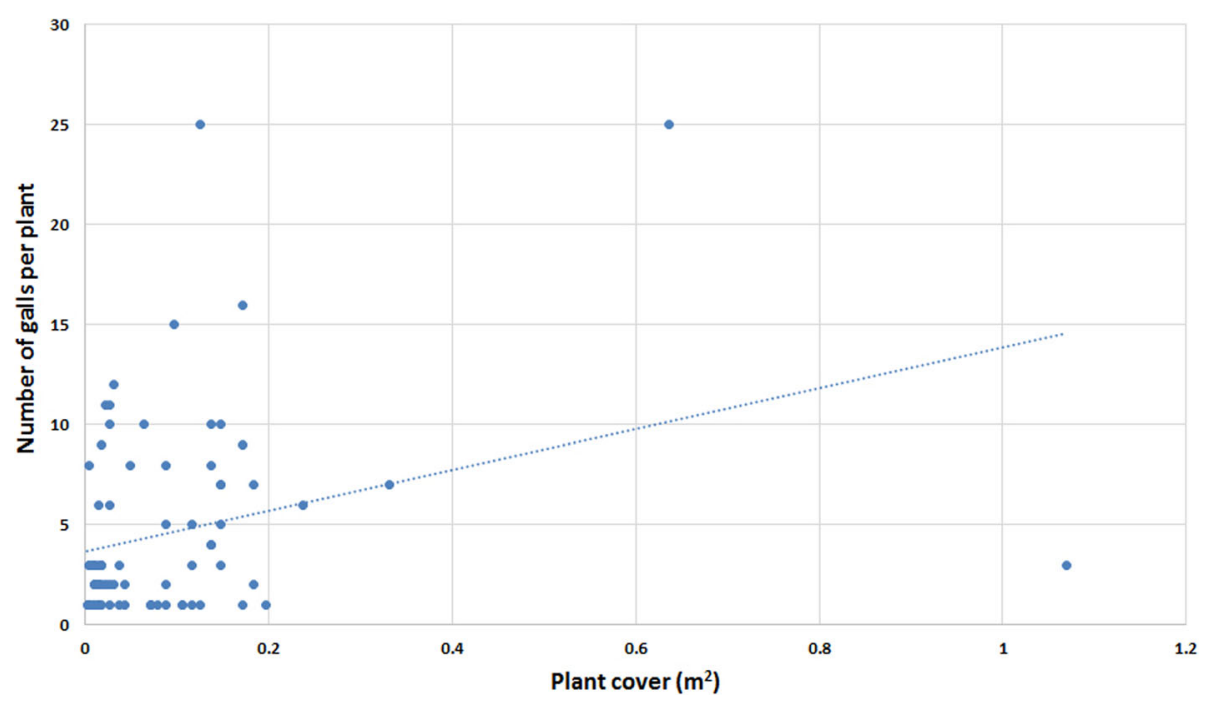

Fig. 4 The relationship between the number of galls per plant and the plant cover within the study localities

Spatial prediction model of the gall midge $S$. buboniae and its host plant $D$. tortuosa in Egypt The predicted distribution range of $S$. buboniae and $D$. tortuosa in Egypt

The MaxEnt model for S. buboniae is shown in Fig. 6. The predicted distribution habitat of $S$. buboniae is mainly concentrated in some areas close to the Mediterranean coast, in addition to some areas in the Nile delta region and the Red Sea coasts. Five presence records were used for training and one for testing. The AUC (Fig. 7) for the training points was 0.994 and for the test points, it was 0.999 , with a standard deviation of -1.000 .
The AUC was greater than 0.90, indicating outstanding discrimination for S. buboniae. The minimum training presence among training points was 57.207. At this threshold, the fractional predicted area was 0.013, and the omission rate for test points was 0.000 . The model classifies the test points correctly significantly more than a random model $(P<0.001)$.

The MaxEnt model for D. tortuosa is shown in Fig. 8. The predicted distribution habitat of $D$. tortuosa covers wide regions of the Mediterranean coast, in addition to some localities in the Nile land region, the Red Sea coast, and South Sinai. Twenty-five presence records

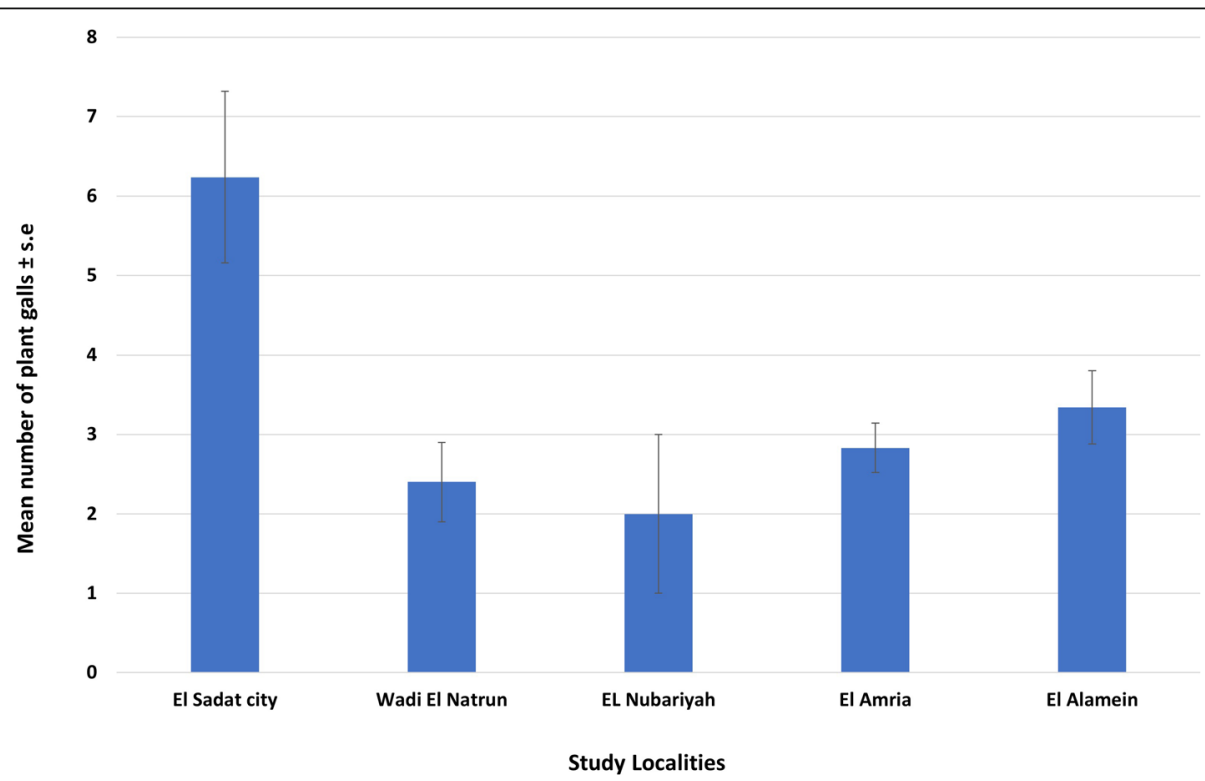

Fig. 5 The spatial pattern of gall distribution on the Deverra tortuosa among different study localities $(F(4,86)=2.611, P<0.05)$ 


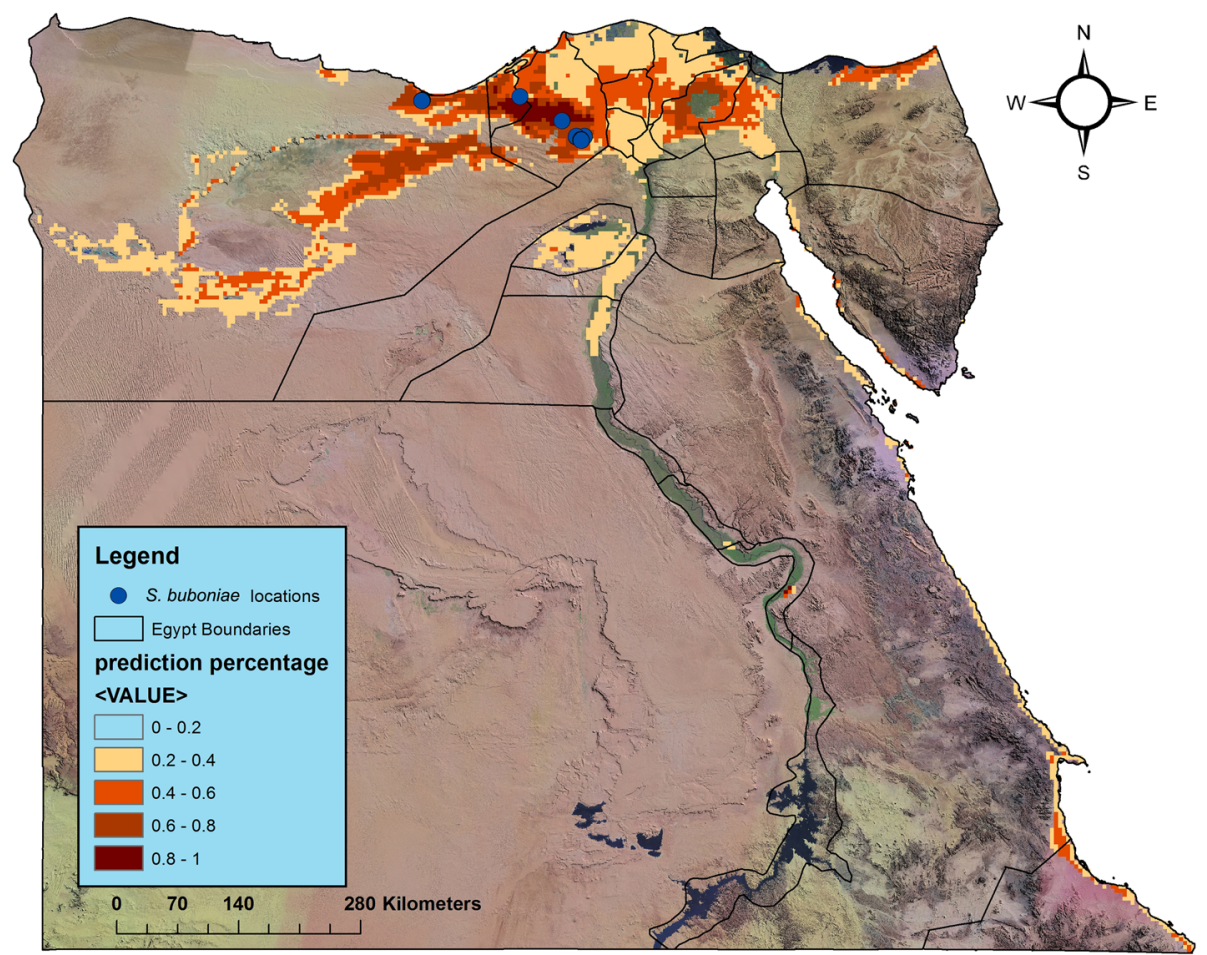

Fig. 6 The predicted distribution range of the S. buboniae according to the MaxEnt model (map source: IESR, GIS unit, and Google Maps https://www.google.com.eg/maps/@27.4846067,31.3939551,6z)

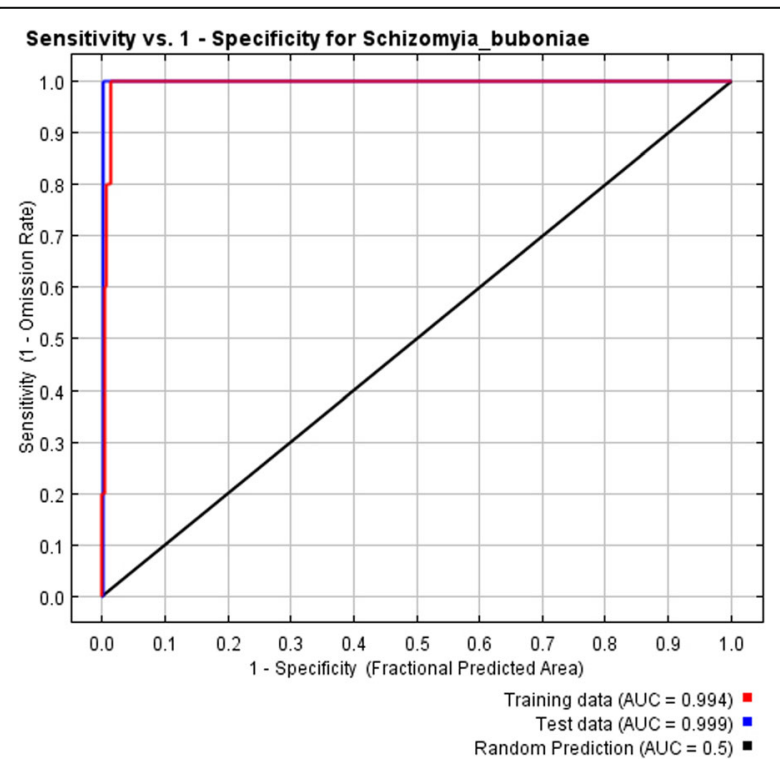

Fig. 7 The predicted distribution range of the D. tortuosa according to the MaxEnt model (map source: IESR, GIS unit, and Google Maps https://www.google.com.eg/maps/@27.4846067,31.3939551,6z) were used for training the model and 8 for testing. The AUC (Fig. 9) for the training points was 0.941, and for the test points, it was 0.934 , with a standard deviation of 0.017. The AUC was greater than 0.90 , indicating outstanding discrimination for $D$. tortuosa. The minimum training presence among training points was 2.115. At this threshold, the fractional predicted area was 0.415 , and the omission rate for test points was 0.000 . The model classifies the test points correctly significantly more than a random model $(P<0.001)$.

\section{Effect of predictor variables in the representation of the MaxEnt model for S. buboniae and $D$. tortuosa in Egypt} According to the analysis of the variables using the percent contribution heuristic test (Fig. 10), S. buboniae showed high sensitivity to altitude, temperature seasonality (BIO4), precipitation of the warmest quarter (BIO18), precipitation seasonality (BIO15), annual mean temperature (BIO1), isothermality (BIO3), and mean temperature of the wettest quarter (BIO8), with contribution percentage equal to $45 \%, 18 \%, 13 \%, 11 \%, 7 \%, 4 \%$, and $2 \%$, respectively.

The MaxEnt model's internal jackknife test of variable importance showed that altitude was the most important predictor of $S$. buboniae habitat distribution. This variable showed higher gains that included the most information as compared to the other variables. 


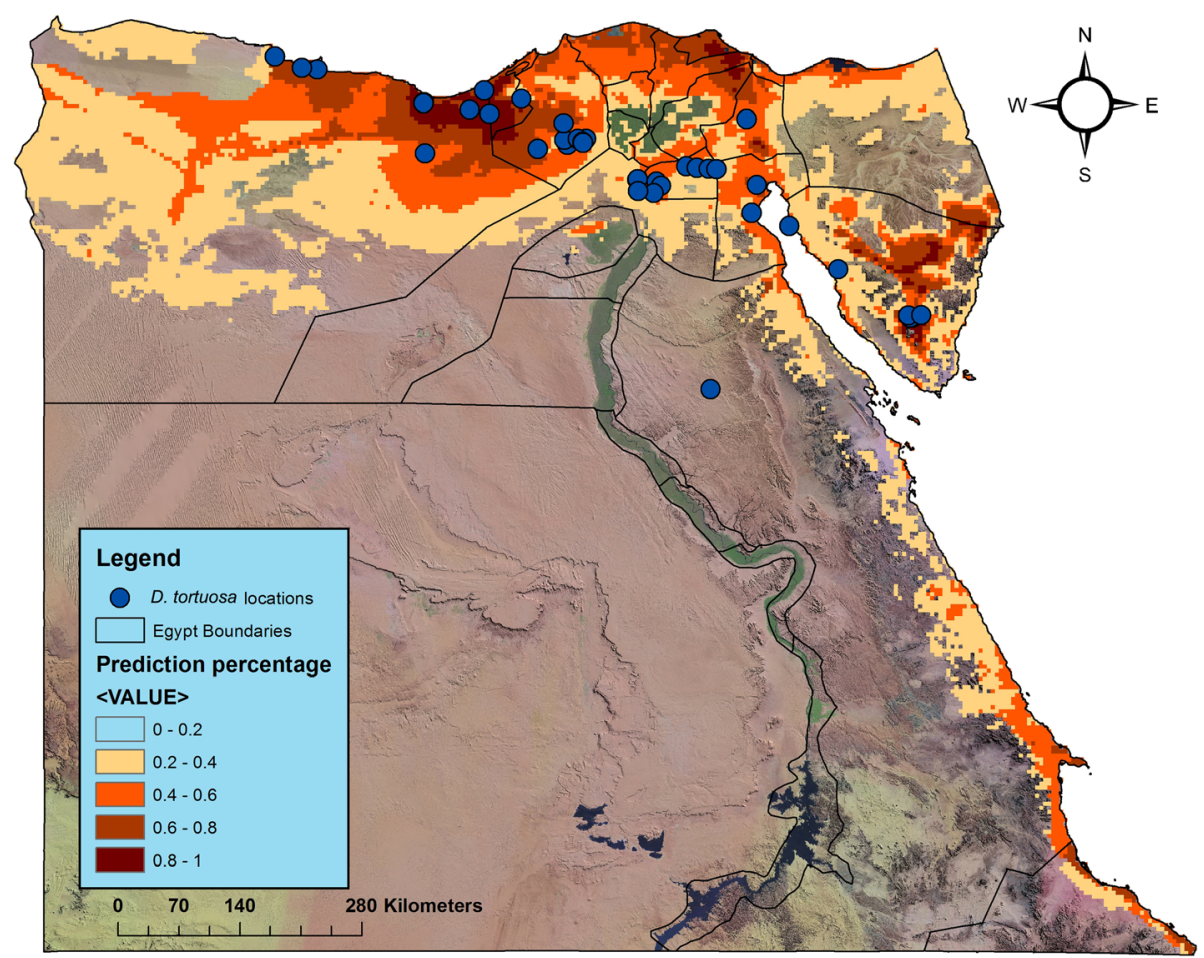

Fig. 8 Training data (AUC $=0.994$ ) and test data $(A \cup C=0.999)$ compared to random prediction $(A \cup C=0.5)$ in the receiver operating characteristic (ROC) curve for the representation of the MaxEnt model for S. buboniae

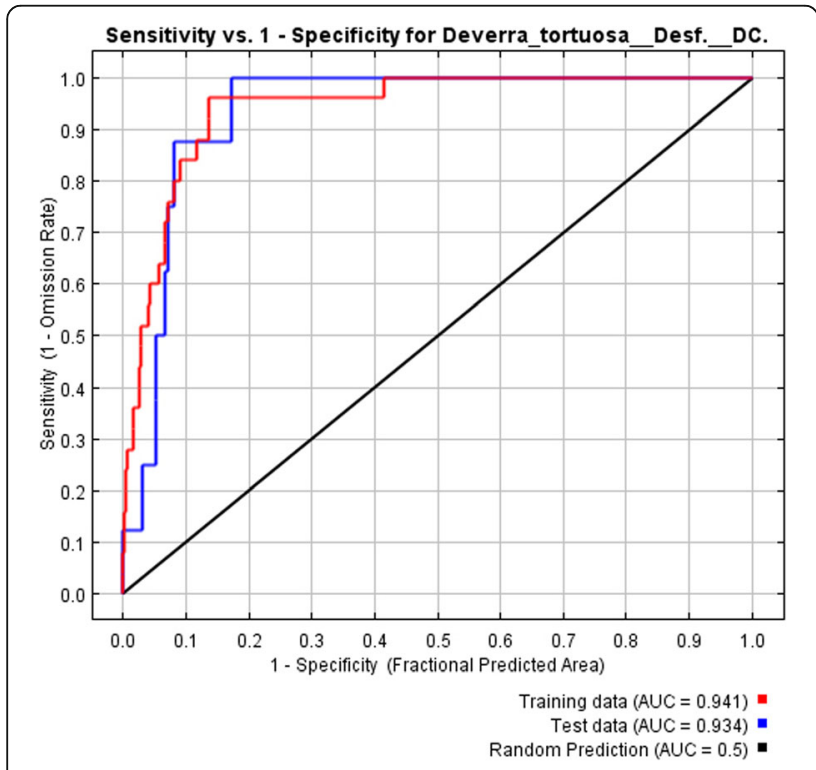

Fig. 9 Training data $(A \cup C=0.941)$ and test data $(A \cup C=0.934)$ compared to random prediction ( $\mathrm{AUC}=0.5$ ) in the receiver operating characteristic $(R O C)$ curve for the representation of the MaxEnt model for D. tortuosa
According to the analysis of the variables using the percent contribution heuristic test (Fig. 11), D. tortuosa showed high sensitivity to temperature seasonality (BIO4), precipitation of the warmest quarter (BIO18), precipitation seasonality (BIO15), temperature annual range (BIO7), mean temperature of the warmest quarter (BIO10), max temperature of the warmest month (BIO5), and precipitation of the wettest quarter (BIO16), with contribution percentage equal to $54 \%, 12 \%, 9 \%, 7 \%$, $7 \%, 6 \%$, and $5 \%$, respectively.

The MaxEnt model's internal jackknife test of variable importance showed that max temperature of the warmest month (BIO5) and precipitation of the warmest quarter (BIO18) were the most important predictors of $D$. tortuosa habitat distribution. These variables presented higher gains that included the most information as compared to the other variables.

\section{Discussion}

A question of great concern in herbivory is how plant traits affect attacks by phytophagous insects (Prado \& Vieira, 1999). According to Price (1991), the plant vigor hypothesis proposes that more potent, energetic, fastgrowing plants will be preferred by several types of herbivores that depend on high meristematic activity, units of large size, or some chemicals of nutritional property related with vigor. The current study suggests that the 


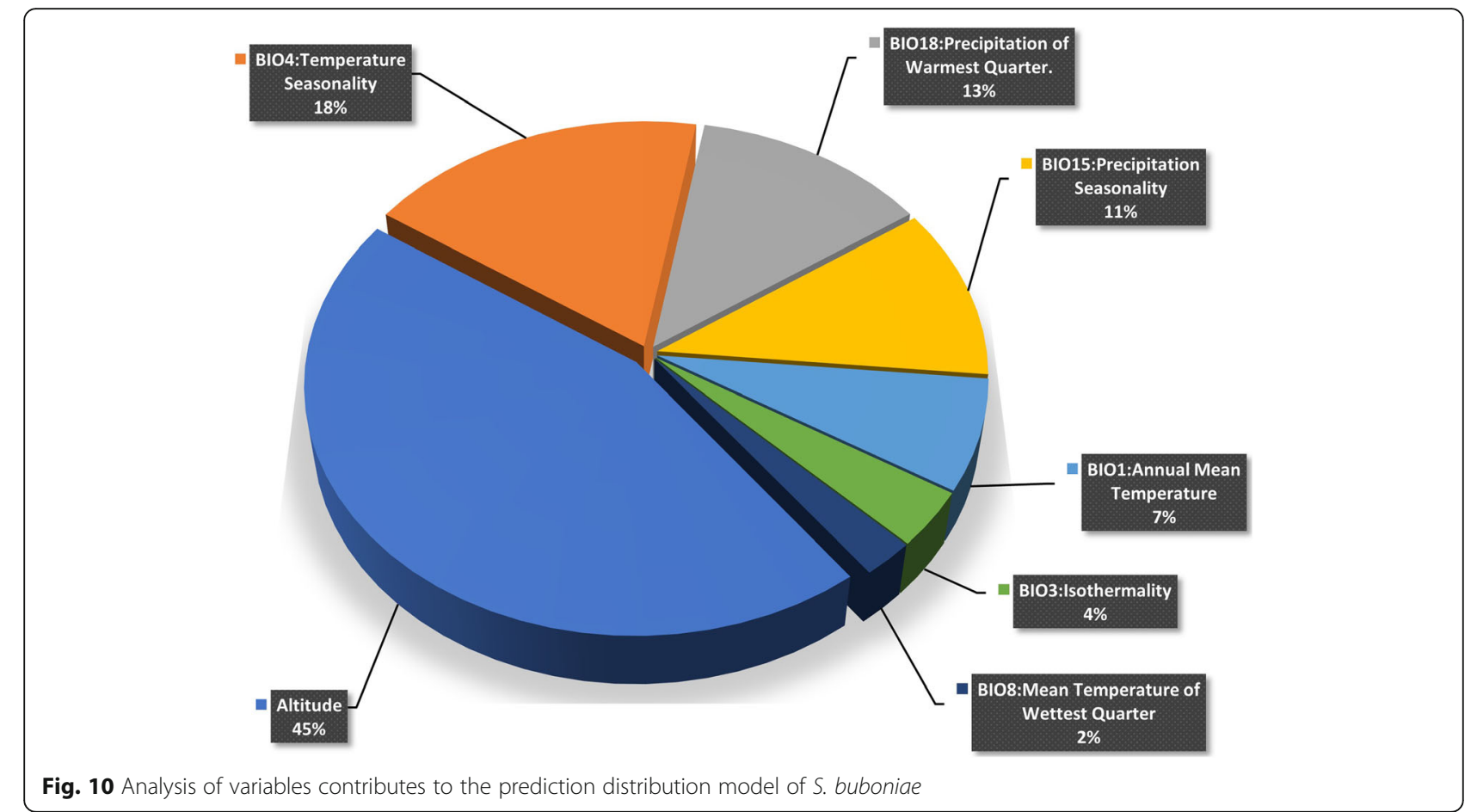

gall inducer prefers the large plants more than the small ones which was clear from the positive correlation between the plant cover and the number of galls per plant. Therefore, the current study supports the plant vigor hypothesis in the case of D. tortuosa. It may be strongly attributed to the availability of resources provided by large plants, which supports the suggestions of Feeny (1975). Gall-inducing insects usually prefer large and fastgrowing plant organs, such as shoots and leaves (Price,
1991). The current study showed that the stem of $D$. tortuosa is one of the most important parts of the plant subjected to gall induction. It may be strongly attributed to the large shoot diameter that may provide enough area for gall induction (De Bruyn, 1994). Also, the gall inducer prefers the more rewarding parts of the plant to form the gall (Whitham, 1978).

The current study suggests that the habitat distribution patterns of $S$. buboniae and its host plant $D$.

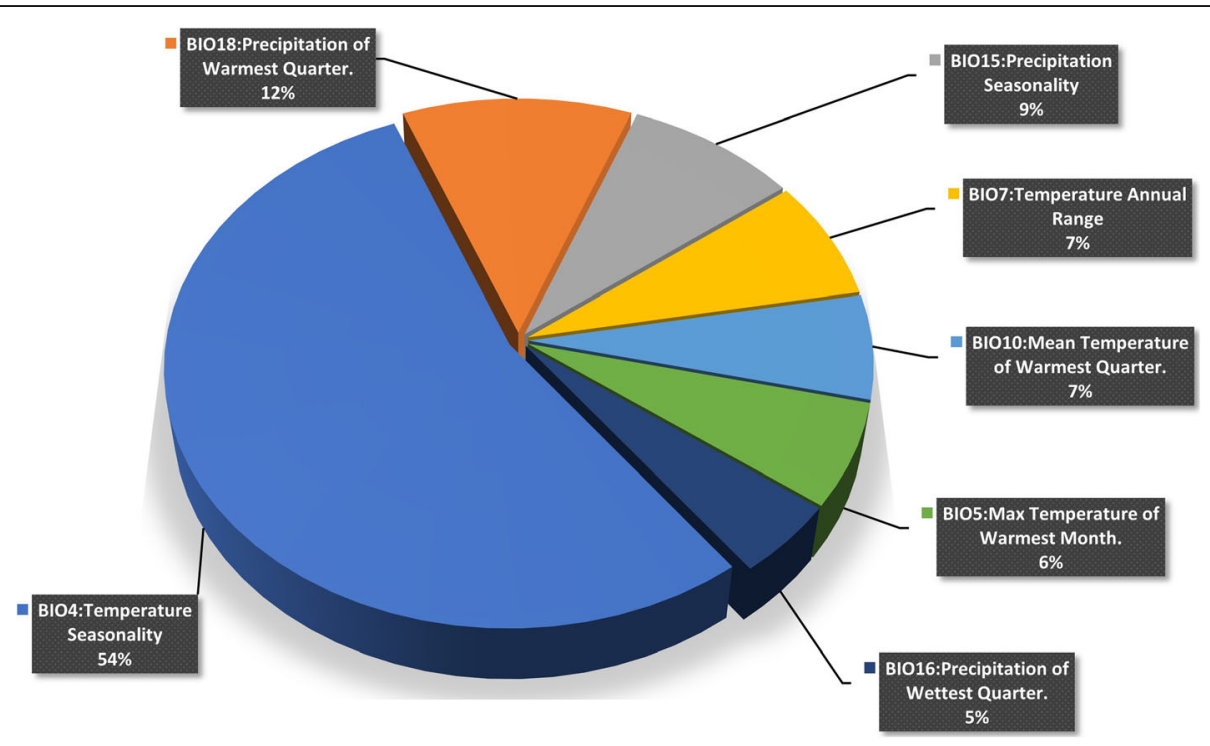

Fig. 11 Analysis of variables contributes to the prediction distribution model of D. tortuosa 
tortuosa in Egypt can be modeled using a small number of occurrence records together with environmental variable layers for the study area through the maximum entropy modeling technique (MaxEnt). So, the present study agrees with the view of Hernandez et al. (2006) and Kamel et al. (2012) who suggested that the MaxEnt technique worked better for species with very small occurrence records that have relatively wide geographic distributions.

The present study suggested that the predicted distribution range size for $S$. buboniae is less than the total predicted distribution range size for $D$. tortuosa. The predicted distribution habitat of $S$. buboniae is mainly concentrated in some areas close to the Mediterranean coast, in addition to some regions in the Nile delta region. This agrees with the findings of Skuhravá et al. (2014) who reported that the distribution of S. buboniae is concentrated in Mediterranean regions, while the predicted distribution habitat of $D$. tortuosa covers a wider region of the Mediterranean coast, in addition to some localities in the Nile land region, the Red Sea coast, and South Sinai. This has concurred with the view of Kamel et al. (2012) and El-Lamey (2015b) who recorded D. tortuosa in different areas of South Sinai.

Gall-inducing insects are perfect models for studies on the specificity and ecological diversity due to their abundance, richness, and sessile habit (Santana \& Isaias, 2014). They possess a high specificity to their host plants and have predictable responses to any changes in the environment (Fernandes et al., 2009).

So, the current study suggested that the gall midge $S$. buboniae can be a vital tool for biodiversity conservation due to its highly specific interaction with the host plant D. tortuosa.

The present study showed that altitude was the most important predictor of $S$. buboniae habitat distribution. This agrees with the findings of Semida (2006) and Kamel et al. (2012) who suggested that altitude is an important variable determining the distribution of gallforming insects. Furthermore, max temperature of the warmest month (BIO5) and precipitation of the warmest quarter (BIO18) were the most important predictors of D. tortuosa habitat distribution. This has concurred with the view of Vasseur et al. (2014) who suggested that most plant species show increases in performance at greater mean temperatures.

Plant galls are remarkable for the association of a complex community of species, other than the gall inducer, belonging to diverse insect groups. These other species may be either parasites that cause the eventual death of the gall maker or "guests" of the gall former "inquilines" that obtain their nourishment from tissues of the gall (Sanver \& Hawkins, 2000). The present study showed that the $S$. buboniae larvae are occasionally attacked by parasitic wasps of the genus Inostemma (Platygastridae, Hymenoptera), which is recorded in plant galls to benefit from the nutrients found in the plant tissue inside the gall. This agrees with the findings of Dorchin and Freidberg (2011) who reported that Inostemma sp. was endoparasitoids for the $S$. buboniae larvae which form stem galls in D. tortuosa in Israel. In contrast, Kamel et al. (2012) showed that Inostemma sp. was the principal gall maker which induced stem galls on $D$. tortuosa in Saint Katherine Protectorate, South Sinai. Therefore, this finding was incorrect according to our results.

\section{Conclusions}

The current study suggests that the gall-making insects prefer large plants more than small ones. The present study suggests that the predicted habitat of $S$. buboniae and its host plant $D$. tortuosa in Egypt can be modeled using a small number of occurrence records together with climatic variable layers for the study area through the maximum entropy modeling technique.

Based on our prediction results and analysis, it is so important to study more about plant gall induction in Egypt as a unique form of insect-plant interactions Additionally, we need to pay more attention to the suitable areas of the gall inducer S. buboniae and its host plant D. tortuosa in Egypt, which should be the important areas for protection.

\section{Abbreviations}

Alt: Altitude; AUC: Area under the curve; Bio1: Annual mean temperature; Bio10: Mean temperature of the warmest quarter; Bio 11: Mean temperature of the coldest quarter; Bio12: Annual precipitation; Bio13: Precipitation of the wettest month; Bio14: Precipitation of the driest month; Bio15: Precipitation seasonality (coefficient of variation); Bio16: Precipitation of the wettest quarter; Bio17: Precipitation of the driest quarter; Bio18: Precipitation of the warmest quarter; Bio19: Precipitation of the coldest quarter; Bio2: Mean diurnal range (mean of monthly (max temp - min temp)); Bio3: Isothermality $($ P2/P7) $(\times 100)$; Bio4: Temperature seasonality (standard deviation $\times 100)$; Bio5: Max temperature of the warmest month; Bio6: Min temperature of the coldest month; Bio7: Temperature annual range (P5-P6); Bio8: Mean temperature of the wettest quarter; Bio9: Mean temperature of the driest quarter; Fig.: Figure; GIS: Geographical information system; m. a. s. I: Meters above sea level; MaxEnt: Maximum entropy modeling technique;

P: Probability; ROC: Receiver operating characteristic; rs: Spearman correlation coefficient; Sig.: Significant; SRTM: Shuttle Radar Topography Mission

\section{Acknowledgements}

Not applicable.

\section{Authors' contributions}

MK, MMM, and SHR collected the data. ASB analyzed the results. MK and SHR interpreted the results of predicting the geographic distribution habitats of Schizomyia buboniae (Diptera: Cecidomyiidae) and its host plant Deverra tortuosa (Family: Apiaceae) in Egypt by using MaxEnt modeling. MK was a major contributor in writing the manuscript. All authors read and approved the final manuscript.

\section{Funding}

This research did not receive any specific grant from funding agencies in the public, commercial, or not-for-profit sectors. 


\section{Availability of data and materials}

The datasets used and/or analyzed during the current study are available from the corresponding author on reasonable request.

\section{Declarations}

Ethics approval and consent to participate

Not applicable.

\section{Consent for publication}

Not applicable.

\section{Competing interests}

The authors declare that they have no competing interests.

\section{Author details}

'Department of Environmental Basic Sciences, Institute of Environmental Studies and Research, Ain shams University, Cairo, Egypt. ${ }^{2}$ Department of Zoology, Faculty of Science, Al-Azhar University, Cairo, Egypt. ${ }^{3}$ Department of Botany and Microbiology, Faculty of Science, Al-Azhar University, Cairo, Egypt.

Received: 24 July 2020 Accepted: 5 May 2021

Published online: 17 May 2021

\section{References}

Abd El-Ghani, M., Bornkamm, R., El-Sawaf, N., \& Turky, H. (2011). Plant species distribution and spatial habitat heterogeneity in the landscape of urbanizing desert ecosystems in Egypt. Urban Ecosystems, 14, 585-616.

Araújo, A. P. A., De Paula, J. D. A., Carneiro, M. A. A., \& Schoereder, J. H. (2006a). Effects of host plant architecture on colonization by galling insects. Austral Ecology, 31(3), 343-348. https://doi.org/10.1111/j.1442-9993.2006.01563.x.

Araújo, M. B., Thuiller, W., \& Pearson, R. G. (2006b). Climate warming and the decline of amphibians and reptiles in Europe. Journal of Biogeography, 33, $1712-1728$

Ascendino, S., \& Maia, V. C. (2018). Insects galls of Pantanal areas in the State of Mato Grosso do Sul, Brazil: Characterization and occurrence. Anais da Academia Brasileira de Ciências, 90(2), 1543-1564. https://doi.org/10.1590/ 0001-3765201820170535.

Azzazi, M., Afifi, M., Tammam, O., \& Sheikh Alsouk, A. (2015). Chemical composition and antifungal activity of the essential oil from Deverra tortuosa against phytopathogenic fungi. Swift Journal of Agricultural Research, 1, 2832

Barbosa, P., \& Wagner, M. R. (1989). Chapter 10 - Gall-forming insects. In P. Barbosa, \& M. R. Wagner (Eds.), Introduction to forest and shade tree insects. Academic Press.

Borges, R. M. (2015). How to be a fig wasp parasite on the fig-fig wasp mutualism. Current Opinion in Insect Science, 8, 34-40. https://doi.org/10.1016/ j.cois.2015.01.011.

Boulos, L. (2000). Flora of Egypt, (vol. 2). Al hadara publishing.

Chrtek, J., Osbornova, J., \& Sourkova, M. (1967). Notes on the genus Deverra (Umbelliferae). Preslia, Praha, 4, 5.

Darvas, B., Skuhravá, M., \& Andersen, A. (2000). Agricultural dipteran pests of the Palaearctic region. Contributions to a Manual of Palaearctic Diptera, 1, 565650.

De Bruyn, L. (1994). Life history strategies of three gall-forming flies tied to natural variation in growth of Phragmites australis. In P. W. Price, W. J. Mattson, \& Y. N. Baranchikov (Eds.), The ecology and evolution of gall-forming insects U.S. Dept. Of agriculture, Forest service, North central forest experiment station.

Doğanlar, M., \& Elsayed, A. K. (2013). Parasitoids complex of Asphondylia conglomerata De STEFANI (Diptera: Cecidomyiidae) on the Mediterranean Saltbush, Atriplex halimus L.(Chenopodiaceae) in Egypt, with descriptions of new species from Eulophidae and Torymidae (Hymenoptera: Chalcidoidea). Linzer Biologische Beiträge, 45, 1799-1811.

Doğanlar, M., \& Elsayed, A. K. (2015). Parasitoids complex in summer populations of Asphondylia punica Marchal, 1897 (Diptera: Cecidomyiidae) on the Mediterranean saltbush, Atriplex halimus L.(Chenopodiaceae) in Egypt, with descriptions of new species from Eupelmidae. Munis Entomology and Zoology, 10, 75-85.
Dorchin, N., \& Freidberg, A. (2011). The gall midges (Diptera: Cecidomyiidae) of Apiaceae in Israel. Zootaxa, 3044(1), 28-48. https://doi.org/10.11646/zootaxa.3 044.1.2.

Dreger-Jauffret, F. (1992). Diversity of gall-inducing insects and their galls. In J. D. Shorthouse, \& O. Rohfritsch (Eds.), Biology of insect-induced galls, (pp. 8-33). Oxford University Press.

El Alqamy, H., Ismael, A., Abdelhameed, A., Nagy, A., Hamada, A., Rashad, S., \& Kamel, M. (2010). Predicting the status and distribution of the Nubian Ibex (Capra nubiana) in the high-altitude mountains of south Sinai (Egypt). Galemys: Newsletter of the Spanish Society for the Preservation, 22, 517-530.

El Hadidi, M. N., \& Hosni, H. A. (1996). Biodiversity in the flora of Egypt. In L. J. G. Van Der Maesen, X. M. Van Der Burgt, \& J. M. Van Medenbach De Rooy (Eds.), The biodiversity of African plants: Proceedings XIVth AETFAT Congress 22-27 August 1994, Wageningen, The Netherlands. Springer Netherlands. https://doi. org/10.1007/978-94-009-0285-5_101.

El-Lamey, T. (2015a). Total phenolic content and antioxidant activity of Deverra tortuosa (desf.) DC. growing in different habitats. Journal of Biological Chemistry \& Envirionmental Sciences 1687-5478, 10, 183-201.

El-Lamey, T. M. (2015b). Contribution of solutes to the osmotic adjustment of Deverra tortuosa (Desf.) DC. Journal of Biodiversity and Environmental Sciences, 7, 380-395.

El-Mokasabi, F. M. (2014). Floristic composition and traditional uses of plant species at Wadi Alkuf, Al-Jabal Al-Akhder, Libya. American-Eurasian Journal of Agricultural \& Environmental Sciences, 14, 685-697.

Elsayed, A. K., \& Karam, H. H. (2016). First record of Planococcus minor (Maskell) (Hemiptera: Pseudococcidae) as a prey of Diadiplosis donaldi (Harris) (Diptera: Cecidomyiidae). Studia Dipterologica, 23(2), 265-266.

Elsayed, A. K., Karam, H. H., \& Tokuda, M. (2017). A new Gephyraulus species (Diptera: Cecidomyiidae) inducing flower bud galls on the European sea rocket Cakile maritima Scop.(Brassicaceae). Applied entomology and zoology, 52(4), 553-558. https://doi.org/10.1007/s13355-017-0508-x.

Elsayed, A. K., Lin, S.-F., Yang, M.-M., \& Tokuda, M. (2020). The first report of the genus Schizomyia (Diptera: Cecidomyiidae) in Taiwan, with description of a new species forming stem galls on Maesa perlaria var. formosana (Primulaceae). Journal of Asia-Pacific Entomology, 23(4), 1083-1088. https:// doi.org/10.1016/j.aspen.2020.08.011.

Elsayed, A. K., Skuhrava, M., Karam, H. H., Elminshawy, A., \& Al-Eryan, M. A. (2015). New records and new species of gall midges (Diptera: Cecidomyiidae) developing on Chenopodiaceae in Egypt. Zootaxa, 3904(1), 105-115. https:// doi.org/10.11646/zootaxa.3904.1.6.

Elsayed, A. K., Wheeler, G. S., Purcell, M., Dyer, K., Zhang, J., \& Tokuda, M. (2019). A new Schizomyia species (Diptera: Cecidomyiidae) inducing flower bud galls on Chinese tallow tree Triadica sebifera in its native range. Applied Entomology and Zoology, 54(4), 429-436. https://doi.org/10.1007/s13355-01900639-9.

Elsayed, A. K., Yukawa, J., \& Tokuda, M. (2018). A taxonomic revision and molecular phylogeny of the eastern Palearctic species of the genera Schizomyia Kieffer and Asteralobia Kovalev (Diptera, Cecidomyiidae, Asphondyliini), with descriptions of five new species of Schizomyia from Japan. ZooKeys, 808(808), 123-160. https://doi.org/10.3897/zookeys.808.29679.

Feeny, P. (1975). Biochemical coevolution between plants and their insect herbivores. Coevolution of animals and plants. University of Texas Press, Austin, Journal of Animal Ecology, 13, 1-8.

Fernandes, G. W., Almada, E. D., \& Carneiro, M. A. A. (2010). Gall-inducing insect species richness as indicators of forest age and health. J Environmental Entomology, 39, 1134-1140.

Fernandes, S. P. C., Castelo-Branco, B. P., Albuquerque, F. A., Brito-Ramos, A. B., Ferreira, A. L. N., Braga, D. V. V., \& Almeida-Cortez, J. S. (2009). Galhas entomógenas em um fragmento urbano de Mata Atlântica no centro de endemismo de Pernambuco. Revista Brasileira de Biociências, 7(3), 240-244.

Frauenfeld, G. (1859). Ueber exotische Pflanzenauswüchse, erzeugt von Insekten. $J$ Verhandlungen der kaiserlichköniglichen zoologisch-botanischen Gesellschaft in Wien, 9, 319-332.

Fritz, R. S., Gaud, W. S., Sacchi, C. F., \& Price, P. W. (1987). Patterns of intra-and interspecific association of gall-forming sawflies in relation to shoot size on their willow host plant. Oecologia, 73(2), 159-169. https://doi.org/10.1007/ BF00377503.

Gagné, R. J., \& Jaschhof, M. (2004). A catalog of the Cecidomyiidae (Diptera) of the world. Entomological Society of Washington DC.

Gagné, R. J., \& Jaschhof, M. (2021). A catalog of the Cecidomyiidae (Diptera) of the world. 
Gerling, D., Kugler, J., \& Lupo, A. (1976). The galls of insects and mites that occu on Tamarix spp. Israel and the Sinai. Bollettino del Laboratorio di Entomologia Agraria "Filippo Silvestri" di Portici, 33, 53-79.

Graham, C. H., \& Hijmans, R. J. (2006). A comparison of methods for mapping species ranges and species richness. Global Ecology biogeography, 15(6), 578587. https://doi.org/10.1111/j.1466-8238.2006.00257.x.

Guisan, A., \& Thuiller, W. (2005). Predicting species distribution: Offering more than simple habitat models. Ecology Letters, 8(9), 993-1009. https://doi.org/1 0.1111/j.1461-0248.2005.00792.x.

Hadidi, M. N. (1981). An outline of the planned 'flora of Egypt'. In V. Täckholm (Ed.), Flora of Egypt. O. Koeltz.

Hebert, P. D. N., Ratnasingham, S., Zakharov, E. V., Telfer, A. C., Levesque-Beaudin V., Milton, M. A., ... Dewaard, J. R. (2016). Counting animal species with DNA barcodes: Canadian insects. Philosophical Transactions of the Royal Society B: Biological Sciences, 371 (1702), 20150333. https://doi.org/10.1098/rstb.2015. 0333.

Hernandez, P. A., Graham, C. H., Master, L. L., \& Albert, D. L. (2006). The effect of sample size and species characteristics on performance of different species distribution modeling methods. Ecography, 29(5), 773-785. https://doi.org/1 0.1111/j.0906-7590.2006.04700.x.

Hijmans, R. J., Cameron, S. E., Parra, J. L., Jones, P. G., \& Jarvis, A. (2005). Very high resolution interpolated climate surfaces for global land areas. International Journal of Climatology, 25(15), 1965-1978. https://doi.org/10.1002/joc.1276.

Hori, K. (1976). Plant growth-regulating factor in the salivary gland of several heteropterous insects. Comparative Biochemistry and Physiology Part B: Comparative Biochemistry, 53(4), 435-438. https://doi.org/10.1016/0305-0491 (76)90193-0.

Hosmer, D. W., Lemeshow, S., \& Cook, E. D. (2000). Applied logistic regression, (2nd ed., ). Wiley. https://doi.org/10.1002/0471722146.

Julião, G. R., Fernandes, G. W., Negreiros, D., Bedê, L., \& Araújo, R. C. (2005). Insetos galhadores associados a duas espécies de plantas invasoras de áreas urbanas e peri-urbanas. Revista Brasileira de Entomologia, 49(1), 97-106. https://doi. org/10.1590/S0085-56262005000100010.

Kamel, M. (2012). Plant galls of Sinai, Egypt. Plant galls induction in St. Katherine protectorate. KG Heinrich-Böcking-Straße, Germany, Lambert Academic Publishing $\mathrm{GmbH} \& \mathrm{Co}$.

Kamel, M. (2021). Hiking trails effects on the diversity of gall-inducing insects in high altitude ecosystem, St. Katherine Protectorate, Egypt. Zoology in the Middle East, 67(1), 48-56. https://doi.org/10.1080/09397140.2020.1859975.

Kamel, M., Semida, F., \& Abdel-Dayem, M. (2012). Galls inducing insects in Sinai Ecosystem, Egypt. Gall inducing insects and their host plants in St. Katherine Protectorate. KG Heinrich-Böcking-Straße, Germany, Lambert Academic Publishing $\mathrm{GmbH} \& \mathrm{Co}$.

Migahid, A. M. (1989). Flora of Saudi Arabia, (vol. 2). King Saud university libraries.

Moreira, R., Fernandes, G., Almada, E., \& Santos, J. (2007). Galling insects as bioindicators of land restoration in an area of Brazilian Atlantic Forest. Lundiana, 8(2), 107-112.

Phillips, S. (2016). A brief tutorial on Maxent, versions: 3.3.1. Lessons in Conservation, 3, 108-135.

Phillips, S. J., Anderson, R. P., \& Schapire, R. E. (2006). Maximum entropy modeling of species geographic distributions. Ecological modelling, 190(3-4), 231-259. https://doi.org/10.1016/j.ecolmodel.2005.03.026.

Phillips, S. J., Dudík, M., \& Schapire, R. E. (2004). A maximum entropy approach to species distribution modeling. In Proceedings of the twenty-first international conference on Machine learning, (p. 83).

Prado, P. I. K., \& Vieira, E. M. (1999). The interplay between plant traits and herbivore attack: A study of a stem galling midge in the neotropics. Ecological Entomology, 24(1), 80-88. https://doi.org/10.1046/j.1365-2311.1999. 00173.x.

Price, P. W. (1991). The plant vigor hypothesis and herbivore attack. Oikos, 1, 244251.

Qi, Y., Wei, W., Chen, C., \& Chen, L. (2019). Plant root-shoot biomass allocation over diverse biomes: A global synthesis. Global Ecology and Conservation, 18, e00606.

Raman, A., Schaefer, C. W., Withers, T. M., \& Enfield, N. H. (2005). Biology, ecology, and evolution of gall-inducing arthropods, (vol. 1 and 2). New Hampshire, Science Publishers Inc., xxi.

Rocha, S., Branco, M., Boas, L. V., Almeida, M. H., Protasov, A., \& Mendel, Z. (2013). Gall induction may benefit host plant: A case of a gall wasp and eucalyptus tree. Tree Physiology, 33(4), 388-397. https://doi.org/10.1093/treephys/tpt009.
Roininen, H., Ohgushi, T., Zinovjev, A., Virtanen, R., Vikberg, V., Matsushita, K., ... Veteli, T. O. (2006). Latitudinal and altitudinal patterns in species richness and mortality factors of the galling sawflies on Salix species in Japan. In Galling arthropods and their associates. Springer.

Royer, T. A. \& Rebek, E. J. 2013. Plant galls caused by insects and mites. Oklahoma Cooperative Extension Fact Sheets.

Santana, A. P., \& Isaias, R. M. D. S. (2014). Galling insects are bioindicators of environmental quality in a conservation unit. Acta Botanica Brasilica, 28(4), 594-608. https://doi.org/10.1590/0102-33062014abb3510.

Santos, M. G., Hanson, P., Maia, V. C., \& Mehltreter, K. (2018). A review of galls on ferns and lycophytes. Environmental Entomology, 48, 53-60.

Sanver, D., \& Hawkins, B. A. (2000). Galls as habitats: The inquiline communities of insect galls. Basic and Applied Ecology, 1(1), 3-11. https://doi.org/10.1078/143 9-1791-00001.

Semida, F. M. M. (2006). Ungulate grazing impact on the local distribution of the rare species Rhopalomyia Tanaceticola karsh. (Diptera: Cecidomyiidae), In South Sinai ecosystem. Bulletin of the Entomological Society of Egypt, 83, 5160.

Serag, M. S., Khedr, A. H. A., \& Amer, N. G. (2020). Ecological and essential oils characteristics of Deverra tortuosai (Desf.) DC. in Egyptian deserts. African Journal of Biological Sciences, 16(1), 11-20. https://doi.org/10.21608/ajbs.2020. 71379.

Skuhravá, M., \& Roques, A. (2000). Palaearctic dipteran forest pests. Contributions to a manual of Palaearctic Diptera, 1, 651-692.

Skuhravá, M., Skuhravý, V., \& Elsayed, A. (2014). Gall midges (Diptera: Cecidomyiidae) of Egypt: Annotated list and zoogeographical analysis. Acta Societatis Zoologicae Bohemicae, 78, 241-268.

Vasseur, D. A., Delong, J. P., Gilbert, B., Greig, H. S., Harley, C. D. G., Mccann, K. S., .. O'connor, M. I. (2014). Increased temperature variation poses a greater risk to species than climate warming. Proceedings. Biological Sciences, 281(1779), 20132612.

Whitham, T. G. J. E. (1978). Habitat selection by Pemphigus aphids in response to response limitation and competition. Ecology, 59(6), 1164-1176. https://doi. org/10.2307/1938230.

Wilson, K. A., Westphal, M. I., Possingham, H. P., \& Elith, J. (2005). Sensitivity of conservation planning to different approaches to using predicted species distribution data. Biological Conservation, 122(1), 99-112. https://doi.org/10.1 016/j.biocon.2004.07.004.

Yamazaki, K., \& Ohsaki, N. (2006). Willow leaf traits affecting host use by the leafgall-forming sawfly. Population Ecology, 48(4), 363-371. https://doi.org/10.1 007/s10144-006-0002-8

Zahran, M., El Demerdash, M., \& Mashaly, I. (1985). On the ecology of the deltaic coast of the Mediterranean Sea, Egypt. 1.-General survey. In 4. Egyptian Conference of Botany. Ismaileyah. 16-19 Apr 1985.

Zahran, M., El-Demerdash, M., \& Mashaly, I. (1990). Vegetation types of the deltaic Mediterranean coast of Egypt and their environment. Journal of Vegetation Science, 1(3), 305-310. https://doi.org/10.2307/3235705.

\section{Publisher's Note}

Springer Nature remains neutral with regard to jurisdictional claims in published maps and institutional affiliations.

\section{Submit your manuscript to a SpringerOpen ${ }^{\circ}$ journal and benefit from:}

- Convenient online submission

- Rigorous peer review

- Open access: articles freely available online

- High visibility within the field

- Retaining the copyright to your article

Submit your next manuscript at $\boldsymbol{\nabla}$ springeropen.com 